American Journal of Clinical Research and Reviews
(ISSN:2576-0505)

\title{
ASSOCIATION BETWEEN PERCEIVED ACADEMIC STRESS AND SUICIDE BEHAVIOR AMONG COLLEGE STUDENTS FROM PERNAMBUCO
}

Renata Alves de Sousa ${ }^{1 *}$, Guilherme Brazão², Péricles Bezerra de Freitas Júnior ${ }^{3}$, Everton Botelho Sougey ${ }^{4}$, Tatiana de Paula Santana da Silva ${ }^{5}$

$1,2,4,5$ UFPE; ${ }^{3}$ FUNESO

\begin{abstract}
OBJECTIVES: To verify whether there is an association between perceived academic stress and suicidal behavior in young people in the university community. METHOD: Cross-sectional study approved by ethics committee $\left(n^{\circ} 2,581,563\right)$, with a sample of 609 undergraduates from the Federal University of Pernambuco from: health, human sciences and exact sciences from 17 to 50 years. For the collection, we used: Mini International Neuropsychiatric Interview, Questionnaire of Academic Experiences reduced version, and a sociodemographic questionnaire. The data were tabulated in the SPSS program in version 21.0. Descriptive and inferential statistical techniques were used for analysis, considering a significance level of $5 \%$. RESULTS: Of the sociodemographic data, $34.6 \%(n=211)$ were in the age group of 21 to 23 years, the majority were female, $64.5 \%(n=393)$. There was a significant difference in economic organization, the university students of human sciences presented lower per capita family income than health students $(p<0.001)$. There was an association between perceived academic stress and suicidal behavior, specifically for ideation $(p<0.001)$ and suicide attempt $(p<0.001)$. Suicidal ideation was present in $44.2 \%$ of those who suffer academic stress, and only present in $24 \%$ who did not report academic stress. $15.5 \%$ of students with academic stress reported previous suicide attempt, while $4.2 \%$ of students without academic stress reported attempting at some point in their lives. CONCLUSION: There was an association between perceived academic stress and suicidal behavior. The data reveal the vulnerability of this group to risk behaviors where academic pressure can intensify such behaviors, and these should be investigated throughout the university segment.

Keywords: Psychological Distress. Student Health. Mental Health

\section{*Correspondence to Author:}

Renata Alves de Sousa

UFPE

How to cite this article:

Renata Alves de Sousa, Guilherme Brazão, Péricles Bezerra de Freitas Júnior, Everton Botelho Sougey, Tatiana de Paula Santana da Silva. ASSOCIATION BETWEEN PERCEIVED ACADEMIC STRESS AND SUICIDE BEHAVIOR AMONG COLLEGE STUDENTS FROM PERNAMBUCO. American Journal of Clinical Research and Reviews, $2021 ; 4: 21$.

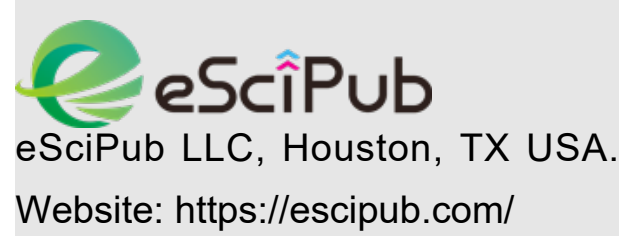
Website: https://escipub.com/
\end{abstract}

